\title{
The Causes of Tragic Marriages and Love in Maugham's Works-from the Perspective of Historical Background
}

\author{
Jinling Xia \\ School of Foreign Language, Wuhan Technology and Business University, \\ Wuhan 430065, China \\ 517504104@qq.com
}

Keywords: tragic love and marriage; historical background; causes of tragic marriages and love

\begin{abstract}
As a productive writer, Maugham creates numerous love stories in his lifetime writing, but most of them end in tragedies. In fact, the tragedies are not only caused by the author's personal experience, technique of writing as well as the artistic conception, but mostly by the historical background. From the perspective of historical background, the paper mainly analyzes the causes of tragic marriages and love in Maugham’s works.
\end{abstract}

\section{Introduction}

William Somerset Maugham (1874-1965) is a famous English realistic writer, who lives in the turn of late 19th century and early 20th century. He is well known as a novelist, playwright and short-story writer. He achieves higher reputation in readers than in critics, and he even says that he is the very best of the second-rate writers of his time. In spite of this, his literature achievement can't be ignored. He is regarded as one of the most popular English writers. Maugham lives for nearly ninety-two years, and his writing career spans almost 65 years, in which he publishes twenty novels, over thirty plays, more than one hundred short stories, as well as a large number of literary criticism, travels and essays, most of which are well received by the readers throughout the world. No doubt, Maugham is a productive as well as a successful writer. As a productive writer, Maugham creates numerous love and marriage stories in his lifetime writing, but most of them are full of frustration and misery, ending in tragedies.

\section{Characteristics of love and marriage stories in Maugham's works}

It can not be neglected that Maugham is expert in telling attractive love and marriage stories in his works. Tracing back to all of his works, it is easy to find that tragic love and marriages occur repeatedly, and characters in love and marriages were often driven into sorrow and misery. From his representative works it is apparent to show that, such as Of Human Bondage, The Moon and Six Pence and The Razor's Edge. For example, his masterpiece Of Human Bondage, which is a semi-autobiographical novel, vividly describes the torturing relation between Philip and Mildred. Philip loves Mildred crazily although he is painfully aware that it's foolish to love such a snobbish and selfish girl as her. However, he can't control his emotion and devotes all his passion to her. As a result, the saying that you reap where you have sown proves totally wrong. Mildred doesn't love him. She cheats him, uses his money, betrays him, and abandons him finally, which severely hurts his indignity. In The Moon and Six Pence, it depicts the inner world of the protagonist Charles Strickland. In order to follow his inner voice, he abandons his wife and children for his ideal of painting. In his eyes, his dream is just like the moon in the sky. Compared with his dream, everything is not worth mentioning, just like six pence on the floor, including his family and love. The Razor's Edge is Maugham's another influential work, which tells the love affair between Larry and Isabel. They love each other, but love does not necessarily lead to marriage in front of material temptation. Isabel turns to Gray and marries him, whom she doesn't love but is born to a wealthy family with promising future. Besides, in Maugham's writing of early drama and later short stories, the theme of distorted love and marriage is also quite common. 
Many researchers comment that Maugham is addicted to abnormal, torturing love and marriages in his writing. John Whitehead ever says Maugham's favorite topic is disloyal marriage ${ }^{[1]}$.Ted Morgan who is a biographer of Maugham comments that Maugham likes to deal with the same subject in his writing that love is a bondage and marriage is a trap ${ }^{[2]}$. Zheng Suhua comes to a conclusion that Maugham's radical and pessimistic attitudes is due to his failure in love and marriage $^{[3]}$. Wang Dongjing thinks that Maugham has an inclination to anti-women based on tragic love and marriage stories in his works ${ }^{[4]}$.

Why does Maugham incline to create tragic love and marriages, but not the happy ones in his work? Is it out of artistic creation? Or is it the reflection of social reality? What are the real causes for this phenomenon? Here, from the angle of historical background, the author will focus on this problem and try to find out the answers.

\section{Analysis of Maugham's intention to create tragic love and marriage stories in his works}

It is evident that Maugham's attitudes towards love and marriage extremely pessimistic and hopeless in his works. This precisely reflects his psychological trauma from his painful experiences. "Trauma profoundly affects both communities and individuals. Therefore, its consequences can be seen as individual problems, but also as problems on the family and societal levels." ${ }^{[5]}$ Naturally, Maugham's traumatic psychology casts shadow to his writing. Here, from the impact of social background, the author analyzes the rooted causes for Maugham's creation of tragic love and marriage stories in his works.

As a long-lived writer, Maugham experiences an era from later Victoria to Edward. Of course, his attitudes towards love and marriage are deeply influenced by the social conditions. In the later Victoria times, the economy of Great Britain trended towards declining from the position of number one in the world, and the artificial optimism of Victoria dynasty gradually disappeared, which caused shadow of crisis to loom large in the whole society. Besides, the remarkable material civilization not only gave birth to the acute class contradictions, but also stirred people's selfish desire. Correspondingly, there was a falling tendency for the social values in Victoria times. In the ideological sphere, people underwent tremendous changes. Upon Charles Darwin's two books coming out, Origin of Species and Evolutionary Theory, people's firm belief in religion began to shake. With the declaration of "God has died," people escaped from the arm of God and broke the bonds of religion completely. Then traditional moral beliefs were challenged, and the most classical religious works of Bible and Gospel lost authority. People felt lost and bewildered. People no longer followed traditional social morals and customs. The traditional virtues of diligence and self-discipline were out of date. People's spiritual family became barren and they trapped in a state of confusion. As a result, pragmatism and materialism flourished, money worships and utilitarianism were quite popular. A distinguishing feature of the times was that material prevailed over the spirit. Freed from the bondage of God, people had no restriction of moral values and they didn't take their misbehavior for serious. Love and marriage was no longer built on true love, but used as tool in exchange of wealth or social status. Maugham, like other people, witnessed the dramatic change and corruption of traditional moral values, which traumatized him a lot. He expressed his disappointment and anger in the works. He used his pen to expose these unhealthy phenomena: women didn't hold the traditional conservative attitudes to love and marriages. In their eyes, love and marriage should produce profit for them. Money and other kinds of profit determine whether they would love or marry someone. True love didn't count. In order to get the material comfort or social status, they could sacrifice everything including love and marriage. Naturally, as a man, Maugham felt intense disgust to this phenomenon. In his eyes, it was just women's twisted moral values that caused the tragedies of love and marriage. So in his works, on one hand, he went to great lengths to show his hatred and condemnation to women. On the other hand, he encouraged men to escape from the bonds of love and marriage. Then love and marriage was not sweet and peaceful in his writing; on the contrary, love and marriage brought much pain and disasters to male and female characters. We can find many such examples in Maugham's works. 


\section{Summary}

To conclude, the impact of social background is a major factor to Maugham's creation of tragic love and marriage stories in his works, which causes Maugham's traumatic psychology. With the transition of social patterns, people experience the spiritual crises, and value alienation becomes the major problem. Love and marriage, as an important form of relationship, becomes twisted and loses its charm. All of these bring traumas to people, including Maugham. So reflected in his writing, his many love and marriage stories finally end in death or splitting up. Besides, love and marriages are always full of cheating, betrayal or torture. Maugham uses his pen to express his negative attitudes to love and marriage and also to the turbulent social conditions.

\section{Acknowledgement}

The author acknowledges the research grants from the guidance program of humanities and social science project in Hubei province (15G153).

Corresponding author: Xia Jinling, Wuhan Technology and Business University, Public English Department, Wuhan 430065, China

\section{References}

[1] Qin Hong. Pessimistic and Radical Views on Marriage in Maugham's works [J], Journal of Yangtze University. 2008 (3):101-103.

[2] Mei Ying, Shu Yun, Xiao Jing Trans. Somerset Maugham--a biography [M].Hu Nan People's Publishing House, 1981: 99, 103

[3] Zheng Suhua. Marital Views in Maugham's Works [J]. Journal of Changchun University of Science and Technology (Social Science), 2012(10):191-193

[4] Wang Dongjing. On Maugham's Inclination of Anti-woman [J]. Journal of Shenyang Normal University (Social Science), 1999(3):73-75

[5] Drozdek, Boris, John P. Wilson. Voices of Trauma: Treating Survivors Across Cultures [M]. Springer US, 2007:12 